\title{
Análise antigênica de Herpesvírus Bovino tipos 1 (BoHV-1) e 5 (BoHV-5) com anticorpos monoclonais*
}

\author{
SUZANA PEREIRA DE MELO BORGES CAIXETA
}

Paulo Michel Roehe (Orientador - UFRGS)

Banca: Ana Cláudia Franco (UFRGS), Cláudio Wageck Canal (UFRGS), Silvia de Oliveira Hübner (UFPel)

\begin{abstract}
Os herpesvírus bovino tipo 1 (BoHV-1) e tipo 5 (BoHV-5) são responsáveis por uma série de patologias em bovinos. A diferenciação entre tipos e subtipos desses vírus é importante para a compreensão da epidemiologia das infecções associadas a eles, assim como para permitir a tomada de medidas de controle adequadas. No presente estudo foram efetuadas análises antigênicas utilizando anticorpos monoclonais (AcMs) preparados contra antígenos específicos de herpesvírus bovinos. Quarenta e cinco amostras virais foram examinadas com um painel de 36 AcMs previamente preparados, em testes de imunoperoxidase em monocamada. Quatro amostras virais, sendo três BoHV-5 e uma BoHV-1, não apresentaram reatividade frente a nenhum dos AcMs avaliados. Oito dos 36 AcMs reagiram com todas as demais 41 amostras de herpesvírus bovinos. Por outro lado, oito amostras virais (três BoHV-5 e cinco BoHV-1) reagiram com todos os AcMs testados. Um AcM foi capaz de diferenciar o subtipo "c" do BoHV-5 das demais amostras. Os demais resultados obtidos sugerem que não há uma clara correlação entre tipos e subtipos genomicamente determinados de herpesvírus bovinos e os AcMs aqui avaliados.
\end{abstract}

Descritores: herpesvírus bovino, anticorpos monoclonais, análise antigênica. 


\title{
Antigenic analysis of bovine herpesvirustype 1 (BoHV-1) and (BoHV-5) using monoclonal antibodies**
}

\author{
SUZANA PEREIRA DE MELO BORGES CAIXETA
}

\author{
Paulo Michel Roehe (Adviser - UFRGS)
}

Committee: Ana Cláudia Franco (UFRGS), Cláudio Wageck Canal (UFRGS), Silvia de Oliveira Hübner (UFPel)

Bovine herpesvirus 1(BoHV-1) and 5 (BoHV-5) are associated to different clinical conditions of cattle. The differentiation between types and subtypes of these viruses maybe important for a better understanding of the epidemiology of bovine herpesvirus infections, as well as to provide support for adequate control measures. In the present study, antigenic analyses were performed with monoclonal antibodies (Mabs) prepared to bovine herpesviruses specific antigens. Fourty five virus isolates/strains were examined with a panel of 36 previously prepared Mabs, immunoperoxidase monolayer assays. Four virus isolates, of which three BoHV-5 and one BoHV-1, did not react with any of the Mabs tested. Eight of the 36 Mabs reacted with all other 41 bovine herpeviruses. On the other hand, eight viruses (three BoHV-5 and five BoHV-1) reacted with all Mabs tested. One Mab was capable of distinguishing BoHV-5 subtype "c" from the other subtypes. Additional results revealed that no clearcut correlation could be established between bovine herpesviruses types and subtypes determinated by molecular methods and the Mabs here evaluated.

Key words: bovine herpesvirus, monoclonal antibodies, antigenic analysis. 